\title{
Interactive comment on "Dehydration and low ozone in the tropopause layer over the Asian monsoon caused by tropical cyclones: Lagrangian transport calculations using ERA-Interim and ERA5 reanalysis data" by Dan Li et al.
}

\section{Anonymous Referee \#1}

Received and published: 22 October 2019

This paper show low ozone and water vapor near the tropopause at Kunming, China, from Balloonsonde measurements. Multiple data sets support these results, e.g., Feng Yun-2D, FengYun-2G, Aura Microwave Limb Sounder (MLS) satellite data. The observed low ozone and low water vapor are attributed to transport of boundary layer air parcels originated from deep convection region associated with tropical cyclones in the western Pacific. Then dehydration of air parcels happens while passing through the coldest temperature region in the UTLS. Dehydration is also linked to convective clouds associated with the cyclone in the pacific. The results also highlight that vertical

Printer-friendly version

Discussion paper 
transport is faster and stronger in ERA5 than ERA-Interim. This situation was observed in two cases 1-8 August 2009 and 10th August 2015.

The Authors have presented the results with sufficient pieces of evidence and justifications. The manuscript should be published in the ACP after the revision.

I have the following few suggestions which authors may consider to include during revision.

In the years 2009 and 2015, there was El Niño in the pacific. Don't you think that vertical transport of air parcels will be influenced by warming at the onset phase of El Niño?

Linkages of dehydration of air mass with convective clouds in the Pacific associated with the cyclone and passage through coldest temperature region are not clear. It should be stated clearly in the discussion section and elsewhere.

It is excepted that the marine boundary layer containing low ozone and high water vapor may get dehydrated near the cold tropopause. Authors have cited several studies reporting poor ozone air arriving near the tropopause from the tropical marine boundary layer, and there is cold trap dehydration near the TTL (page 2 Lines2-50). What are the new results?

Authors should highlight the implications of low ozone and low water vapor in the abstract and conclusions.

Do you see low ozone and low water vapor values during the passage of cyclone, and low values disappears after that? Daily plots from 7-13 August 2009 and 3-18 August 2015 will be helpful.

Dehydration and ice formation can be shown in a figure from ERA5 and ERA-Interim to support the results.

The authors should show a vertical profile-plot showing the difference between ozone 
on 8 August 2009 and daily climatological mean. A similar plot for water vapor will be useful. Also, similar plots for ozone and water vapor on 10 August 2015 should be shown in supplementary figures. It will help to quantify the decrease in ozone and water vapor at different altitudes on the respective days.

Do you have observations that show low ozone and water vapor outside the cyclone days? Is it a regular feature near the TTL over China during August? Or is there stronger dehydration during cyclone days due to clouds (cumulonimbus) reaching the tropopause?

Page $11 \mathrm{~L}$ 212-215: These statements are confusing. What is the reason for the dehydration of air parcel? Is it related to the deep convective clouds or due to the passage of air parcels through cirrus clouds?

One can use brightness temperature and optical thickness, both, to determine the presence of convective cloud or cirrus cloud.

The method adopted for identification of convective cloud should be mentioned in section 3.1.1.

Figure-1 shows geopotential height at 150 on 4,5, and 6 August 2009. Why not during all the days from 4-8 August 2009?

Page 5-6: The outflow of deep convection is stronger on 6 August 2009 while the vertical profile of ozone and water vapor shows a low amount on 8 August 2009, Why?

Profiles of ozone show minimum ozone at a different height on 4th and 8 August 2009. Is it due to the distance of a cyclone from the observational site?

Page 12 Case 2: 10 August.

On 3 August 2015, intensity typhoon Soudelor reached Category 5. The authors should state the reason for showing analysis on 10 August 2015 when the typhoon was degraded to depression. Balloon measurements are available from 3 to 18 August 2015

Printer-friendly version

Discussion paper 
(Page 3, L74). The authors should present a case for any day during 2-3 August 2015.

Page 7, L 147, and Page 13L 246: If authors want to show vertical profiles which has no influence of cyclone, then profiles should be presented for the days before the formation of cyclone in the Pacific. Profiles on 4 August 2009 and 5 August 2015 are influenced by the cyclonic winds since on these days Morakot, and Soudelor cyclones were passing through the Pacific. If authors want to show the influence of cyclones, then profiles should be shown on the same days at Naha and Kunming. Is there any reason for choosing different days? If so, please clarify.

ASM anticyclone is associated with a large amount of water vapor and low ozone. However, authors want to show that deep convective clouds associated with cyclone, which reaches near the tropopause (cold cloud tops), cause freeze-drying at the outflow of ice clouds. It should be made clear in the abstract and conclusions.

Figures: fonts of $\mathrm{X}$-axis and $\mathrm{Y}$-axis in all the figures should be bigger and bold.

Interactive comment on Atmos. Chem. Phys. Discuss., https://doi.org/10.5194/acp-2019-816, 2019. 